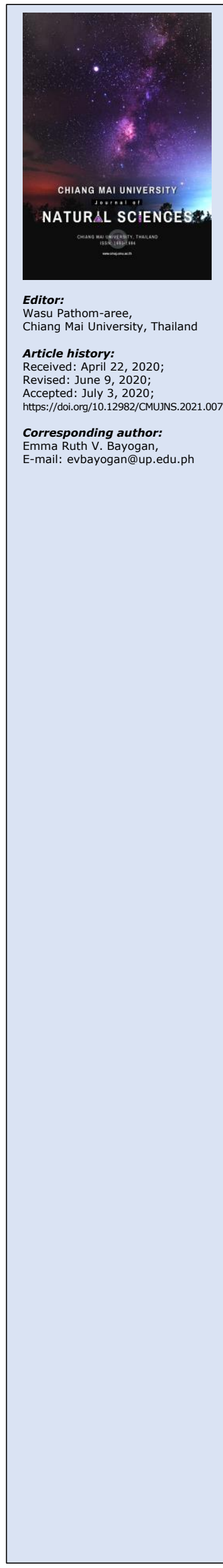

Research article

\title{
Postharvest Quality of 'Carabao' Mango as Affected by Spun-Bound Bagging Materials
}

Leizel Secretaria1, Emma Ruth Bayogan ${ }^{1}$, Christine Diana Lubaton ${ }^{1}$, Anastacia Nortate ${ }^{2}$, and Jennifer Ekman ${ }^{3}$

1 Department of Biological Sciences and Environmental Studies, University of the Philippines Mindanao, Davao del Sur, Philippines 2 College of Agriculture and Related Sciences (CARS) - Tagum-Mabini Campus, University of Southeastern Philippines,

Davao del Norte, Philippines

3 Applied Horticultural Research, Biomedical Building, Australian Technology Park, Eveleigh, NSW, Australia

Abstract $A$ safe option to address some production problems such as insect damage, diseases, and blemishes in mango is fruit bagging. 'Carabao' mango fruit at 55 days after flower induction (DAFI) were bagged with three bagging materials: old newspaper (control), spun-bound high density polyethylene (SHDPE, DuPont ${ }^{T M}$ Tyvek $^{\circledR}$ Homewrap, $0.15 \mathrm{~mm}$ thick) and non-woven spunbound polypropylene (NSPP, $0.03 \mathrm{~mm}$ thick). Bagged mango fruit were harvested at 118 DAFI. At harvest, NSPP bagging material resulted in better quality of fruit compared to newspaper and SHDPE. Advanced color change was observed both in newspaper and SHDPE at 4 and 8 days after harvest (DAH). Compared to newspaper and SHDPE, slower color change was observed in fruit bagged with NSPP up to $8 \mathrm{DAH}$. The degree of anthracnose infection did not differ among bagging materials. Higher degree of stem end rot (SER) infection was noted in newspaper at table ripe stage (TRS). Onset of SER was delayed by about a day in NSPP and SHDPE. At 8 DAH, lowest weight loss was observed in mango bagged with newspaper. Slightly longer shelf life of about a day $(0.72 \mathrm{~d})$ was noted in NSPP-bagged fruit. Shelf life was reduced in newspaper which may be attributed to fruit reaching TRS faster by a day and earlier onset of SER. Total soluble solids in fruit bagged with SHDPE was lower upon harvest and during storage at 8 days while firmness did not vary among bagging materials. NSPP showed potential as bagging material that can maintain better quality of 'Carabao' mango fruit.

Keywords: Bagging, Mango, Non-woven spun bound polypropylene, Preharvest, stem end rot

Citation: Secretaria, L., Bayogan, E.R., Lubaton, C.D., Nortate, A., and Ekman, J. 2021. Postharvest quality of 'Carabao' mango as affected by spun-bound bagging materials. CMUJ. Nat. Sci. 20(1): e2021007. 


\section{INTRODUCTION}

'Carabao' mango is among the top exported fresh fruit next to banana and pineapple in the Philippines. There is an increasing demand of mango fruit in the international market as it is exported not only in Asia but also to North America and Europe (Elauria et al., 2015). Losses remain high despite the increasing demands of 'Carabao' mango which may contribute to inadequate supply of mango both in the local and foreign markets. The susceptibility of mango to various insect infestations, pathogens and mechanical damages contributes to the losses in quality and value (Sharma et al., 2014).

One of the tools to address various production problems in mango to maintain an acceptable peel quality is preharvest bagging of fruit. This approach has gained increasing attention as substitute to chemical method to ensure farmers' safety, consumers' health, and environmental protection (Sharma et al., 2014). Bagging in mango is commonly practiced as an alternative approach to control pests which adversely affect fruit quality. It is a simple, low-cost, and safe method to produce good quality of fruit.

During fruit development, mango fruit at specific maturity is usually bagged to protect the fruit from pests and pathogens causing diseases. In 'Carabao' mango, bagging is usually done at 55-77 days after flower induction (Bugante et al., 1997). In Taiwan, bagging is widely practiced at 30-45 days before harvesting to protect fruit from fruit fly damage (Shu et al., 2000). The use of bagging materials in mango was found to be effective in controlling pest infestation such as fruit fly (Sarker et al., 2009) and incidence of stem end rot (Hofman et al., 1997). Bagging in 'Carabao' mango improved the percentage of export quality fruit (Bayogan et al., 2006). The physical qualities of bagged mango such as weight, length, and diameter of fruit were also improved unlike non-bagged fruit (Haldankar et al., 2015). Different bagging materials were studied for its efficacy in maintaining good quality of fruit. Bagging in mango with single white bag was reported to affect peel color of fruit mango (Wu et al., 2013). Different bagging materials such as butter paper bag, muslin cloth bag and scurting bag improved fruit retention and reduced incidence of mealy bug in 'Alphonso' mango (Haldankar et al., 2015).

In the Philippines, 'Carabao' mango is commonly bagged with old newspaper, a cheap and readily available bagging material. This study evaluated the effect of three different bagging materials in 'Carabao' mango such as newspaper and two materials from Australia namely spun-bound high density polyethylene and non-woven spunbound polypropylene.

\section{MATERIALS AND METHODS}

The preharvest bagging of mango study was conducted in the Provincial Mango Research and Extension Center (PMREC), San Isidro, Babak, Island Garden City of Samal (GPS: $\left.7^{\circ} 10^{\prime} 09.0^{\prime \prime} \mathrm{N} 125^{\circ} 43^{\prime} 21.3^{\prime \prime E}\right)$, Davao del Norte, Mindanao, Philippines. Bagging was done when mango fruit have reached 55 days after flower induction (DAFI) or when fruit were the size of a chicken egg. Fruit thinning was not done after bagging nor does the variety have subtended leaves present in each fruit. Flowering was induced by spraying the leaves with $\mathrm{KNO}_{3}(6 \mathrm{~kg}$ per $200 \mathrm{~L}$ of water). Fungicides were applied before bagging of fruit while the trees were rainfed and applied with fertilizers when needed. Fruit were bagged using three bagging materials namely: old newspaper (0.026 mm thick), spun-bound high density polyethylene (SHDPE) (DuPont ${ }^{\mathrm{TM}}$ Tyvek $^{\circledR}$ Homewrap) (0.15 mm thick) and non-woven spun-bound polypropylene (NSPP) or fleece $(0.032 \mathrm{~mm}$ thick) (Figure 1$)$. Only the rectangular SHPDE bag was cut at its bottom corners. All the bagging materials were fastened to the fruit using staple wires. Fruit were harvested at 118 DAFI. Fruit maturity was determined by counting the days from flower induction. The quality of fruit was assessed immediately after harvest and in the laboratory during storage under ambient conditions. 


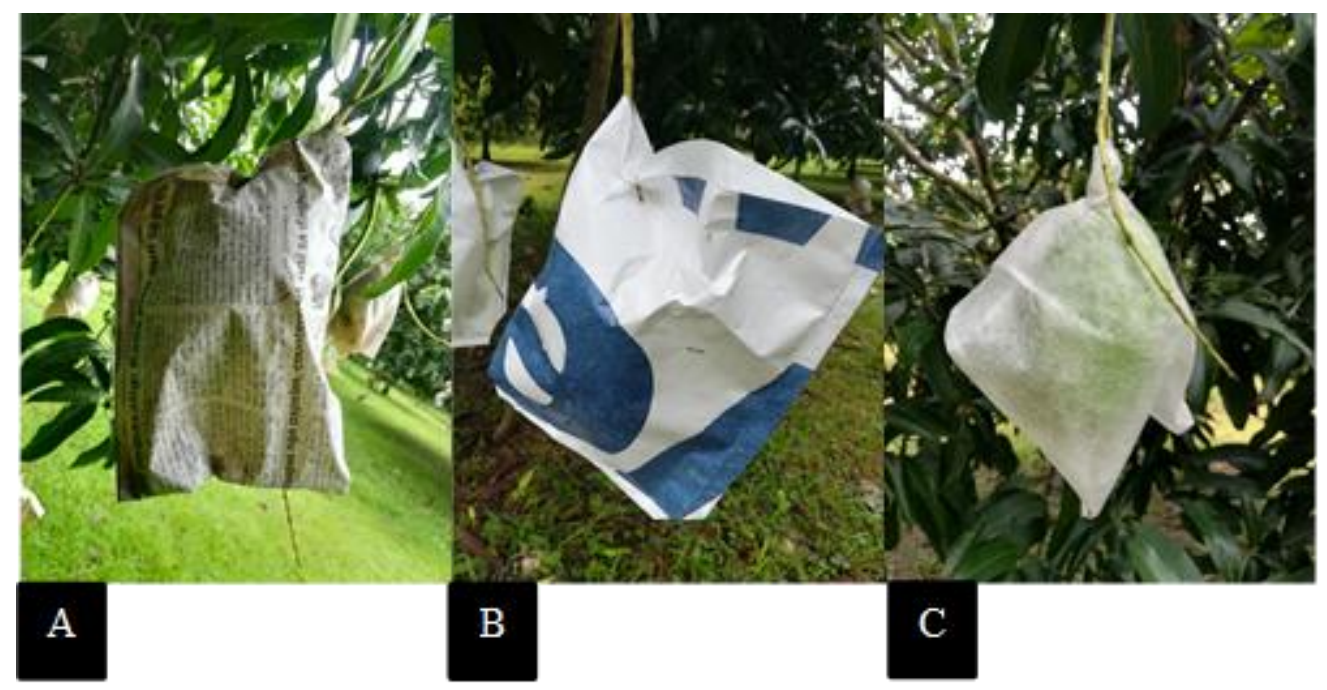

Figure 1. The three bagging materials namely: old newspaper (A), spun-bond high density polyethylene (SHDPE) (DuPont ${ }^{\mathrm{TM}}$ Tyvek $^{\circledR}$ Homewrap) (B) and nonwoven spun-bond polypropylene (NSPP) or fleece (C).

At the farm, from three mango trees, a total of 100 randomly selected mango fruit were identified for each bagging material. Each mango tree had samples for each of the bagging materials. Each treatment was replicated three times using three trees. Visual quality and preharvest quality defects were observed at harvest from 50 randomly selected fruit from each bagging material. Preharvest quality defects observed in the harvested mango fruit included insect pest, scab, sooty mold, lenticel spotting, skin browning, growth cracks, wind scar, and undersized fruit. Preharvest quality defects of fruit were evaluated according to the most distinct and prominent preharvest quality defect from the 50 randomly selected fruit per bagging material.

For postharvest quality evaluation, 50 fruit of uniform medium size and visual quality per bagging material were transported to the Postharvest Biology Laboratory in the University of the Philippines Mindanao. The samples were stored in ambient room conditions ( $27.25 \pm 0.69{ }^{\circ} \mathrm{C}$ and $\left.82.76 \pm 0.69 \% \mathrm{RH}\right)$ and evaluated at 4 and 8 days after harvest (DAH) and at table ripe stage (TRS).

Data gathered were percentage of weight loss, visual quality, peel color index (PCI), degree of anthracnose and stem end rot, days to onset of decay, shelf life and days to table ripe stage (TRS). The fruit reached the TRS when it attained a smooth texture, PCI 5 or 6 and sweet aroma while the end of shelf was attained when fruit reached a visual quality and decay ratings of 4 and 2, respectively. Visual quality was assessed using the scale: 1 = excellent, no symptoms of deterioration; 2 = good, minor symptoms of deterioration that are not objectionable; $3=$ fair, evident deterioration but not serious, limit of saleability; $4=$ poor, serious deterioration, limit of usability; and, 5 = extremely poor, unusable (Ekman et al., 2019). Color change was observed using a PCI with a 1 to 6 scale: $1=$ green; 2 = breaker, a trace of yellow at the stem-end; 3 = turning, more green than yellow; $4=$ more yellow than green; $5=$ yellow with traces of green; and 6 = fully yellow (Ekman et al., 2019). The degree of anthracnose and stem end rot diseases were measured using a slightly modified anthracnose and stem end rot scale as used by Alvindia and Acda (2015) where $1=$ no visible spots and $6=$ depressed spots emerged for anthracnose, and $1=$ no discoloration at the stem end and $6=50 \%$ discoloration of the fruit surface initiated by stem end rot. Total soluble solids and fruit firmness were measured using a handheld digital refractometer (ATAGO PAL-1) and Wagner fruit tester, respectively.

Data were analyzed using Analysis of Variance (ANOVA). Treatment means were compared using Tukey's Test at $P \leq 0.05$. 


\section{RESULTS}

\section{Quality of freshly harvested mango bagged with different materials}

The two bagging materials used: spun-bound high density polyethylene (DuPont ${ }^{\mathrm{TM}}$ Tyvek $^{\circledR}$ Homewrap) or SHDPE and non-woven spun-bound polypropylene (NSPP) or fleece, came from Australia while the newspaper, a common bagging material in the Philippines, served as control. Although not significant, both newspaper and NSPP bagging materials tended to show fruit exhibiting good quality with minor defects, at $44 \%$ and $54 \%$, respectively (Figure 2). Fruit bagged with SHDPE tended to show the lowest visual quality score with more fruit exhibiting fair with evident defects $(28 \%)$ and poor quality $(26 \%)$. Among bagging materials, the NSPP bagging material resulted in better quality of fruit compared to newspaper and SHDPE which exhibited a similarly low visual quality score of 2.8 and 3.1 , respectively (Table 1 ). Fruit bagged with the three bagging materials had similar fruit weights at harvest ranging from 288 to $304 \mathrm{~g}$.

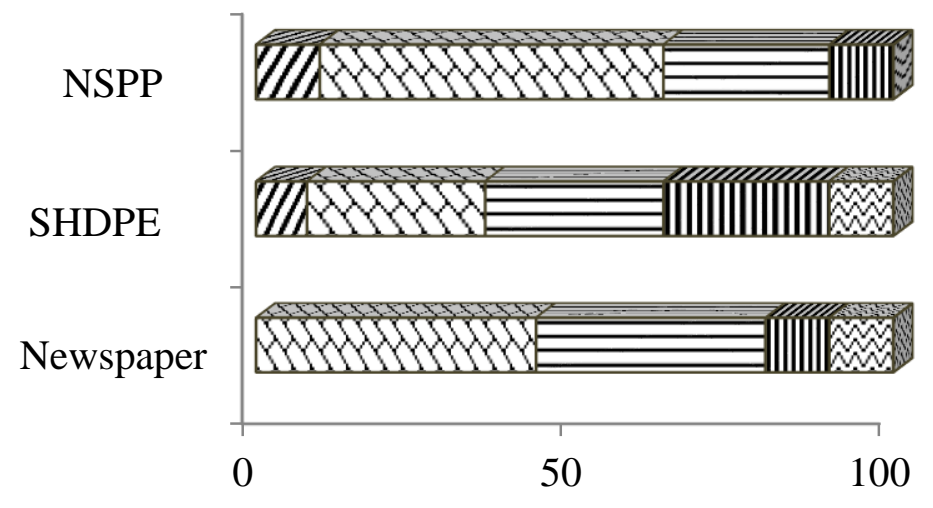

$\mathbf{v Q R} 1$, Excellent

Q VQR 2, Good, minor defects

曰 VQR 3, Fair, evident defects

II VQR 4, Poor, serious defects

Q VQR 5, Extremely poor

Figure 2. Percentage of 'Carabao' mango exhibiting a particular visual quality score as affected by different bagging materials. Note: SHDPE- spun-bound high density polyethylene (DuPont ${ }^{\mathrm{TM}}$ Tyvek ${ }^{\circledR}$ Homewrap); NSPP- non-woven spun-bound polypropylene (fleece).

Table 1. Visual quality of 'Carabao' mango as affected by different bagging materials.

\begin{tabular}{lll}
\hline Bagging Material & Visual quality at harvest & Weight at harvest, g \\
\hline Newspaper & $2.82^{\mathrm{a}}$ & $304.33^{\mathrm{a}}$ \\
SHDPE & $3.06^{\mathrm{a}}$ & $287.67^{\mathrm{a}}$ \\
NSPP & $2.36^{\mathrm{b}}$ & $289.23^{\mathrm{a}}$ \\
\hline
\end{tabular}

Note: Means in a column with a common letter and not common letters are not significantly different using Tukey's at $5 \%$ level of significance. Visual quality: 1 = excellent, no symptoms of deterioration; $2=$ good, minor symptoms of deterioration that are not objectionable; 3 = fair, evident deterioration but not serious, limit of saleability; $4=$ poor, serious deterioration, limit of usability; and, $5=$ extremely poor, unusable. SHDPE- spun-bound high density polyethylene (DuPont ${ }^{\text {TM }}$ Tyvek $^{\circledR}$ Homewrap); NSPP- non-woven spun-bound polypropylene (fleece). 


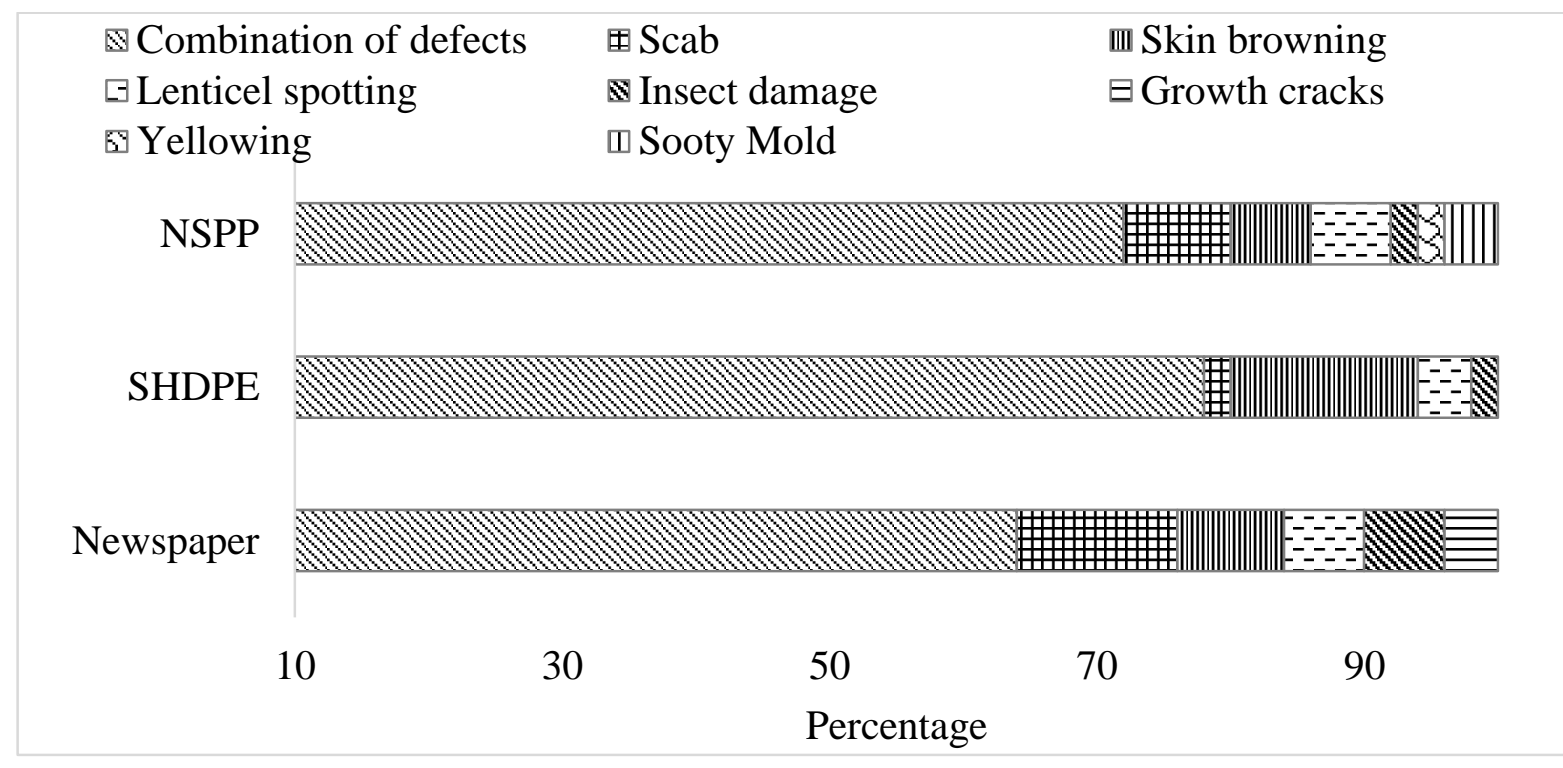

Figure 3. Different quality defects in 'Carabao' mango as affected by bagging materials. Note: SHDPE- spun-bound high density polyethylene (DuPont ${ }^{\mathrm{TM}}$ Tyvek $^{\circledR}$ Homewrap); NSPP- non-woven spun-bound polypropylene (fleece).

The more distinct quality defects observed in bagged mango were scab, lenticel spotting, growth cracks, sooty molds, and skin browning (Figure 3). However, the percentage of defects were not significant among bagging materials. More fruit exhibited a combination of distinct quality defects such as blackspot, undersized fruit, wind scar and/or fruit cracks along with one or more other distinct quality defects mentioned earlier. Scab was the most prevalent quality defect in the three bagging materials followed by skin browning and lenticel spotting. Insect damage was least among the quality defects observed in mango which was absent in fruit bagged with NSPP. SHDPE tended to show a higher percentage of fruit that showed a combination of defects thus reducing the visual quality score (3.06).

\section{Physical quality of bagged 'Carabao' mango during storage}

The visual quality of mango bagged with different materials varied at 4 and 8 days after harvest (DAH) (Table 2) in which newspaper and NSPP bagged fruit had better quality of fruit. Advanced color change from green to yellow was observed both in newspaper and SHDPE-bagged fruit (Table 2). Bagging using NSPP resulted in slightly delayed color change up to $8 \mathrm{DAH}$. Weight loss in bagged mango were similar, except at $8 \mathrm{DAH}$ (Table 2). Lowest weight loss was observed in mango bagged with newspaper, followed by fruit bagged with NSPP. Fruit bagged with SHDPE hastened weight loss as early as $4 \mathrm{DAH}$ though it only varied with the newspaper-bagged samples at $8 \mathrm{DAH}$.

Degree of anthracnose infection did not differ among bagging materials while the degree of stem end rot infection varied at table ripe stage (TRS, Table 2). Stem end rot in NSPP and SHDPE was low with fruit showing up to $10 \%$ discoloration at the stem end. The first day of occurrence of anthracnose was similar among bagging materials while the time to stem end rot varied. In comparison to the newspaper, onset of stem end rot was delayed by about a day in NSPP and SHDPE. Longer days to TRS was noted in NSPP-bagged fruit which resulted in longer shelf life that did not vary with SHDPE (Table 3). Compared to the control, slightly longer shelf was observed in both NSPP and SHDPE. The reduced shelf life in newspaper-bagged fruit may be attributed to fruit reaching TRS faster by a day and earlier onset of SER. 
Table 2. Visual quality and peel color of 'Carabao' mango held in ambient room conditions ( $27.25 \pm 0.69{ }^{\circ} \mathrm{C}$ and $82.76 \pm 0.69$ as affected by bagging materials $\left.\% \mathrm{RH}\right)$.

\begin{tabular}{llccc}
\hline Bagging Material & Initial & 4DAH & 8DAH & TRS \\
\hline Newspaper & $1.70^{\mathrm{a}}$ & Visual quality & & \\
SHDPE & $1.87^{\mathrm{a}}$ & $2.10^{\mathrm{b}}$ & $3.00^{\mathrm{b}}$ & $3.50^{\mathrm{a}}$ \\
NSPP & $1.67^{\mathrm{a}}$ & $2.50^{\mathrm{a}}$ & $3.73^{\mathrm{a}}$ & $3.94^{\mathrm{a}}$ \\
& & $2.10^{\mathrm{b}}$ & $3.48^{\mathrm{a}}$ & $3.69^{\mathrm{a}}$ \\
Newspaper & $1.00^{\mathrm{a}}$ & Peel color & & \\
SHDPE & $1.00^{\mathrm{a}}$ & $2.77^{\mathrm{a}}$ & $5.44^{\mathrm{a}}$ & $6.00^{\mathrm{a}}$ \\
NSPP & $1.00^{\mathrm{a}}$ & $2.60^{\mathrm{a}}$ & $5.17^{\mathrm{a}}$ & $5.83^{\mathrm{a}}$ \\
& & $1.87^{\mathrm{b}}$ & $4.86^{\mathrm{b}}$ & $6.00^{\mathrm{a}}$ \\
Newspaper & - & Weight loss, \% & & \\
SHDPE & - & $3.60^{\mathrm{a}}$ & $8.49^{\mathrm{b}}$ & $11.96^{\mathrm{a}}$ \\
NSPP & - & $4.29^{\mathrm{a}}$ & $11.14^{\mathrm{a}}$ & $10.51^{\mathrm{a}}$ \\
& & $4.16^{\mathrm{a}}$ & $8.84^{\mathrm{a}}$ & \\
NewSpaper & $1.00^{\mathrm{a}}$ & Stem end rot & & $3.30^{\mathrm{a}}$ \\
SHDPE & $1.00^{\mathrm{a}}$ & $1.00^{\mathrm{a}}$ & $2.44^{\mathrm{a}}$ & $2.33^{\mathrm{b}}$ \\
NSPP & $1.00^{\mathrm{a}}$ & $2.04^{\mathrm{a}}$ & $2.76^{\mathrm{b}}$ \\
& $1.00^{\mathrm{a}}$ & $1.00^{\mathrm{a}}$ & $2.28^{\mathrm{a}}$ & \\
NewSpaper & $1.00^{\mathrm{a}}$ & Anthracnose & & $3.14^{\mathrm{a}}$ \\
SHDPE & $1.00^{\mathrm{a}}$ & $1.00^{\mathrm{a}}$ & $2.25^{\mathrm{a}}$ & $4.00^{\mathrm{a}}$ \\
NSPP & $1.00^{\mathrm{a}}$ & $1.00^{\mathrm{a}}$ & $4.00^{\mathrm{a}}$ & $3.20^{\mathrm{a}}$ \\
\hline
\end{tabular}

Note: Per parameter, means in a column with a common letter and not common letters are not significantly different using Tukey's at 5\% level of significance. SHDPE- spun-bound high density polyethylene (DuPont ${ }^{\mathrm{TM}}$ Tyvek ${ }^{\circledR}$ Homewrap); NSPP- non-woven spun-bound polypropylene (fleece). DAH-days after harvest. Visual quality: $1=$ excellent, no symptoms of deterioration; 2 = good, minor symptoms of deterioration that are not objectionable; 3 = fair, evident deterioration but not serious, limit of saleability; $4=$ poor, serious deterioration, limit of usability; and, $5=$ extremely poor, unusable. Peel color: $1=$ green; 2 = breaker, a trace of yellow at the stem end; $3=$ turning, more green than yellow; $4=$ more yellow than green; 5 = yellow with traces of green; and $6=$ fully yellow. Stem end rot: $1=$ no discoloration of the stem end, 2 -discoloration limited at the stem end, $3=10 \%$ discoloration of the fruit surface area initiated by stem end rot, $4=11-30 \%$ discoloration of the fruit surface area initiated by SER, 5= 31-50\% discoloration of the surface area initiated by stem end rot, $6=$ more than $51 \%$ discoloration of the surface area initiated by stem end rot. Anthracnose: $1=$ no visible spots, $2=$ one depressed spot, dark in color with 1-5 mm in diameter on the epidermis of the fruit, $3=2-3$ depressed spots, dark in color with $1-5 \mathrm{mmm}$ in diameter, $4=2-3$ depressed spots, dark in color with more than $5 \mathrm{~mm}$ in diameter, $5=$ more than 3 depressed spots, dark in color with more than $5 \mathrm{~mm}$ in diameter, 6- depressed spots merged.

Table 3. Days to table ripe stage (TRS), onset of stem end rot (SER) and anthracnose and shelf of 'Carabao' mango held in ambient room conditions (27.25 $\pm 0.69{ }^{\circ} \mathrm{C}$ and $82.76 \pm 0.69 \% \mathrm{RH})$ as affected by bagging materials.

\begin{tabular}{lllll}
\hline Bagging Material & Days to TRS & Days to onset of SER & $\begin{array}{l}\text { Days to onset of } \\
\text { anthracnose }\end{array}$ & Shelf life, d \\
\hline Newspaper & $7.75^{\mathrm{b}}$ & $6.67^{\mathrm{b}}$ & $8.07^{\mathrm{a}}$ & $8.07^{\mathrm{b}}$ \\
SHDPE & $7.89^{\mathrm{b}}$ & $7.10^{\mathrm{a}}$ & $7.43^{\mathrm{a}}$ & $8.17^{\mathrm{a}}$ \\
NSPP & $8.64^{\mathrm{a}}$ & $7.60^{\mathrm{a}}$ & $7.80^{\mathrm{a}}$ & $8.79^{\mathrm{a}}$
\end{tabular}

Note: Means in a column with a common letter and not common letters are not significantly different using Tukey's test at $5 \%$ level of significance. SHDPE- spun-bound high density polyethylene (DuPont ${ }^{\top M}$ Tyvek $^{\circledR}$ Homewrap); NSPP- nonwoven spun-bound polypropylene (fleece).

\section{Total soluble solids (TSS) and firmness of bagged 'Carabao' mango during storage}

Bagging materials affected the TSS but not the firmness of 'Carabao' mango which showed a decreasing trend during storage (Table 4). Mango bagged with newspaper consistently showed higher TSS from harvest and during storage. Compared to newspaper and NSPP, SHDPE showed lowest TSS at 8 DAH. Upon attaining TRS, however, TSS did not vary among bagged mango. 
Table 4. Total soluble solids (TSS) and firmness of 'Carabao' mango held in ambient room conditions $\left(27.25 \pm 0.69^{\circ} \mathrm{C}\right.$ and $\left.82.76 \pm 0.69 \% \mathrm{RH}\right)$ as affected by bagging materials.

\begin{tabular}{|c|c|c|c|c|}
\hline \multicolumn{4}{|c|}{ TSS, \% Brix } & TRS \\
\hline Newspaper & $7.84^{a}$ & $12.18^{\mathrm{a}}$ & $16.73^{\mathrm{a}}$ & $19.19^{\mathrm{a}}$ \\
\hline SHDPE & $6.66^{b}$ & $8.99^{a}$ & $14.40^{\mathrm{b}}$ & $17.28^{a}$ \\
\hline NSPP & & $6.42^{\mathrm{b}}$ & $10.08^{a}$ & $17.83^{\mathrm{a}}$ \\
\hline \multicolumn{5}{|c|}{ Firmness, kgF } \\
\hline Newspaper & $7.92^{\mathrm{a}}$ & $4.17^{\mathrm{a}}$ & $1.18^{\mathrm{a}}$ & $0.35^{\mathrm{a}}$ \\
\hline SHDPE & $6.90^{a}$ & $4.00^{a}$ & $0.34^{a}$ & $0.25^{\mathrm{a}}$ \\
\hline NSPP & $6.67^{a}$ & $5.50^{\mathrm{a}}$ & $0.42^{\mathrm{a}}$ & $0.21^{\mathrm{a}}$ \\
\hline
\end{tabular}

Note: Per parameter, means in a column with a common letter and not common letters are not significantly different using Tukey's at $5 \%$ level of significance. DAH- days after harvest; TRS- table ripe stage; SHDPE- spun-bound high density polyethylene

\section{DISCUSSION}

Bagging is a safe and cheap physical technique to protect fruit from quality defects such as wind damage, blemishes, diseases, and pest infestation like insect damage during production. However, despite the protection provided by bagging, preharvest quality defects still limit the marketability of fruit. Scab is a prevalent quality defect observed in 'Carabao' mangoes which was also reported in other areas in the Philippines (Bugante et al., 1997; Bayogan et al., 2006). Scab, caused by the fungus [Sphaceloma mangifera (Elsinoe mangifera)], is characterized by grayish brown spots with irregular dark margins which intensify as cracks and fissured corky tissue (The Mango Technical Committee, 1994). Other defects reported in 'Carabao' mango are wind scar, sooty mold, undersized and distinct veins which were also reported by Bayogan et al. (2006) and Bugante et al. (1997).

The weight of 'Carabao' mango did not vary among bagging materials as was also reported in 'Keitt' mango (Hofman et al., 1997) and 'Sensation' mango (Joyce et al., 1997). In contrast, weight was improved in newspaper- and brown paper- bagged 'Alphonso' (Haldankar et al., 2015); and red agrail-bagged 'Keitt' mango (Abdel GawadNehad et al., 2017). The varietal differences, time of bagging and type of bagging materials may have contributed to the different responses of mango to bagging (Joyce et al., 1997; Sharma et al., 2014).

The spun-bound high density polyethylene (SHDPE) has a tough structure with extremely small pores that resist bulk water and air penetration while allowing vapor to pass through (E.I. du Pont de Nemours and Company, 2007). The water and air resistant properties of SHDPE might have reduced fruit quality due to its inability to fully drain the water inside the bag in case of rain, although a precaution was done by cutting both corners at the bottom of the bag. Despite this precaution, moisture inside the bag might have been retained and caused fruit defects like skin browning and growth cracks.

The adverse effect of higher humidity in the plastic bag persisted after ripening in 'Alphonso' mango (Haldankar et al., 2015). A similar microenvironment may have existed in SHDPE-bagged fruit which may have affected the 'Carabao' mango resulting in lower visual quality and higher weight loss during storage. Joyce et al. (1997) reported a higher weight loss in plastic-bagged 'Sensation' mango. They suggested that the low vapor pressure deficit in the plastic bag might have influenced the development of cuticle structure and/or lenticel. The reduced thickness, stiffness and decrease in the stress needed to break the cuticle has been reported in fruit exposed to higher relative humidity (Matas et al., 2005; Lara et al., 2009). Further, the wax structure of the cuticle might have been modified as it is one of the primary barriers to water loss in fruit (Yeats and Rose, 2013; Isaacson et al., 2009). The cuticle might have become thinner and/or wax structure might have been modified in 'Carabao' mango bagged with SHDPE resulting in higher weight loss. 
The initial quality of mango bagged with newspapers was deemed better and fruit had lower weight loss during storage. However, earlier peel color change, days to table ripe stage and onset of stem end rot (SER), higher degree of SER resulted in reduced shelf life of fruit by less than a day. On the other hand, delayed onset and lower degree of SER in both NSPP and SHDPE resulted in longer shelf life of fruit. A reduction of diseases such as SER and anthracnose was also reported in bagged mango fruit (Hofman et al., 1997; Lamine Senghor et al., 2007). It is still unclear how bagging reduced the diseases, but it was suggested that it could be due to reduced contact of fruit to disease propagules and increased natural disease resistance during ripening (Hofman et al., 1997).

The non-woven spun-bound polypropylene (NSPP) or fleece, used as plant protection, has a very fine mesh that is effective in conserving heat, preventing excessive transpiration, excluding insect pest while allowing good ventilation and passage of water (Akelah, 2013). The fleece is also used to optimize plant growth as it modifies the plant's natural environment (Olle and Bender, 2010). These characteristics of NSPP may have contributed to its efficacy as bagging material in 'Carabao' mango resulting in $20 \%$ better quality than fruit bagged with newspaper, reduction of SER, and a slightly longer shelf life.

The higher total soluble solids (TSS) in 'Carabao' bagged with newspaper compared to NSPP and SHDPE was due to advanced ripening of fruit. Similarly, higher TSS was recorded in 'Alphonso' mango bagged with newspaper and in 'Zill' mango bagged with a single layer white material (Wu et al., 2013; Haldankar et al., 2015). A positive effect of bagging on the alteration of the content and proportion of carbohydrate, carotenoid, and organic acids has been reported during ripening of mango fruit (Zhao et al, 2013).

The firmness of mango was not affected by the bagging materials. Firmness declined through time indicating softening of the fruit during storage. In contrast, bagging of 'Sensation' mango bagged with plastic bag softened faster than the newspaper and non-bagged fruit (Joyce et al., 1997). The white paper bag in 'Keitt' mango delayed the softening compared to non-bagged fruit (Hofman et al., 1997). The variation in fruit softening as influenced by the different bagging materials may indicate the differences of the fruit skin composition and structure (Amarante et al., 2002).

\section{CONCLUSION}

The use of bagging materials as a technique to address some preharvest problems in mango was evaluated in 'Carabao' mango. 'Carabao' mango fruit at 55 days after flower induction (DAFI) were bagged using three bagging materials: old newspaper, spun-bound high density polyethylene (SHDPE, DuPont ${ }^{\mathrm{TM}}$ Tyvek $^{\circledR}$ Homewrap, $0.15 \mathrm{~mm}$ thick) and nonwoven spun-bond polypropylene (NSPP, $0.03 \mathrm{~mm}$ thick). At harvest (118 DAFI) and during storage, 'Carabao' mango quality was affected by bagging materials. Better quality of fruit in NSPP bagging material was observed compared to newspaper and SHDPE. A slower color change up to 8 days after harvest (DAH) in fruit bagged with NSPP was observed compared to advanced color change in newspaper and SHDPE. This advanced color change in newspaper-bagged mango resulted in higher total soluble solids, higher degree of stem end rot infection, and slightly reduced shelf life. Weight loss varied only at $4 \mathrm{DAH}$. Degree of anthracnose and firmness did not differ among bagging materials. Onset of stem end rot was delayed by about a day in NSPP and SHDPE. Longer shelf life was noted in NSPP-bagged fruit due to better quality and delayed onset of stem end rot. Based on these results, NSPP has potential as bagging material that can maintain better quality of 'Carabao' mango fruit. The use of old newspaper as bagging material is a cheaper method compared to the use of NSPP. However, the beneficial effect of NSSP may outweigh the cost of the material. 


\section{REFERENCES}

Abdel Gawad-Nehad, M.A., EL-Gioushy, S.F., and Baiea, M.H.M. 2017. Impact of different bagging types on preventing sunburn injury and quality improvement of Keitt mango fruits. Middle East Journal of Agriculture Research. 6: 484-494.

Akelah, A. 2013. Functionalized Polymeric Materials in Agriculture and the Food Industry. Springer, London.

Alvindia, D.G., and Acda, M.A. 2015. Revisiting the efficacy of hot water treatment in managing anthracnose and stem-end rot diseases of mango cv. 'Carabao'. Crop Protection. 67: 96-101.

Amarante, C., Banks, N.H. and Max, S. 2002. Effect of preharvest bagging on fruit quality and postharvest physiology of pears (Pyrus communis). New Zealand Journal of Crop and Horticultural Science. 30: 99-107.

Bayogan, E.V., Esguerra, E.B., and Campeon, R.T. 2006. 'Carabao' mango harvest quality and production practices and problems of growers in Davao Oriental, Philippines. Acta Horticulturae. 699: 103-110.

Bugante Jr, R.D., Lizada, M.C.C., and de Ramos, M.B. 1997. Disease control in Philippine 'Carabao' mango with preharvest bagging and postharvest hot water treatment. Acta Horticulturae. 455: 797-807.

Ekman J.H., Goldwater A., Bayogan, E.V., Secretaria L.B., Lacap, A.T., Lubaton, C.C., Monterde, V.G., Benitez, M.M., Valida, A.D., Sudaria, E.E., et al. 2019. Improved postharvest management of fruit and vegetables in the Southern Philippines and Australia. Final Report. HORT 2012/098, Australian Centre for International Agricultural Research.

Elauria, M.M., Manilay, A.A., and Abrigo, G.N.A. 2015. Adoption and socio-economic impacts of the pre-harvest disease management technology for 'Carabao' mango in the Philippines. Journal of Economics, Management and Agricultural Development. 1: 1-14.

E.I. du Pont de Nemours and Company. 2007. DuPont ${ }^{T M}$ Tyvek ${ }^{\circledR}$ HomeWrap $®$ physical properties data sheet. Retrieved on October 5, 2019 from Website:http://www2.dupont.com/Tyvek_Weatherization/en_US/assets/downl oads/K-05031HWProd.pdf.

Haldankar, P.M., Parulekar, Y.R., Kireeti, A., Kad, M.S., Shinde, S.M., and Lawande, K.E. 2015. Studies on influence of bagging of fruits at marble stage on quality of mango cV. Alphonso. Journal of Plant Studies. 4: 12-20.

Hofman, P.J., Smith, L.G., Joyce, D.C., Johnson, G.L., and Meiburg, G.F. 1997. Bagging of mango (Mangifera indica 'Keitt') fruit influences fruit quality and mineral composition. Postharvest Biology and Technology. 12: 83-91.

Isaacson ,T., Kisma, D.K., Matas, A.J., Buda, G.J., He, Y., Yu, B., Pravitasari, A., Batteas, J.D., Stark, R.E., Jenks, M.A., and Rose, J.K.C. 2009. Cutin deficiency in the tomato cuticle consistently affects resistance to microbial infection and biochemical properties, but not transpirational water loss. The Plant Journal. 60: 364-377.

Joyce, D.C, Beasley, D.R., and Shorter, A.J. 1997. Effect of preharvest bagging on fruit calcium levels, and storage and ripening characteristics of 'Sensation' mangoes. Australian Journal of Experimental Agriculture. 37: 383-389.

Lamine Senghor, A., Liang, W.J. and Ho, W.C. 2007. Integrated control of Colletotrichum gloeosporioides on mango fruit in Taiwan by the combination of Bacillus subtilis and fruit bagging. Biocontrol Science and Technology. 17: 865-870.

Lara, I., Heredia, A., and Domínguez, D. 2019. Shelf life potential and the fruit cuticle: the unexpected player. Frontiers in Plant Science. 10: 1-18.

Matas, A.J., López-Casado, G., Cuartero, J., and Heredia, A. 2005. Relative humidity and temperature modify the mechanical properties of isolated tomato fruit cuticles. American Journal of Botany. 92: 462-468.

Olle, M., and Bender, I. 2010. The effect of non-woven fleece on the yield and production characteristics of vegetables. Agraarteadus. 1: 24-29.

Sarker, D., Rahman, M.M., and Barman, J.C. 2009. Efficacy of different bagging materials for the control of mango fruit fly. Bangladesh Journal of Agricultural Research. 34: 165-168. 
Sharma, R.R., Reddy, S.V.R., and Jhalegar, M.J. 2014. Pre-harvest fruit bagging: a useful approach for plant protection and improved post-harvest fruit quality - a review. Journal of Horticultural Science and Biotechnology. 89: 101-113.

Shu, Z.H., Yen, C.R., Ke, L.S., Lin, T.S., Shiesh, C.C., Wang, D.N., and Liu, M.F. 1999. Mango production in Taiwan. Acta Horticulturae. 509: 87-94.

The Mango Technical Committee. 1994. The Philippines Recommends for Mango. Los Baños, Laguna: PCARRD and PARRFI. 124pp. (PCARRD Philippines Recommends Series No. 38-A/1994).

Wu, H.X., Wang, S.B., Ma, X.W., Ma, W.H., Zhan, R.L., and Yao, Q.S. 2013. Effect of bagging on fruit quality in mango. Acta Horticulturae. 992: 587-592.

Yeats, T. H., and Rose, J. K. C. 2013. The formation and function of plant cuticles. Plant Physiology. 163: 5-20.

Zhao, J.J., Wang, J.B., Zhang, X.C., Li, H.L., and Gao, Z.Y. 2013. Effect of bagging on the composition of carbohydrate, organic acid and carotenoid contents in mango fruit. Acta Horticulturae. 992: 537-542.

OPEN access freely available online

Chiang Mai University Journal of Natural Sciences [ISSN 16851994]

Chiang Mai University, Thailand

https://cmuj.cmu.ac.th 